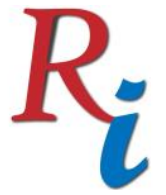

Asia Proceedings of Social Sciences

(APSS)

www.readersinsight.net/APSS

\title{
PILOT STUDY: INDICATOR IN EQUIVALENCE CHECKING FOR APEL
}

\section{Mohd Amin, N. F. M.*}

Faculty of Technical and Vocational Education

Universiti Tun Hussein Onn Malaysia

Malaysia

\section{Kaprawi, N.}

Faculty of Technical and Vocational Education

Universiti Tun Hussein Onn Malaysia

Malaysia

*Corrosponding author's Email: Farhah zai@yahoo.com

Author's Biography

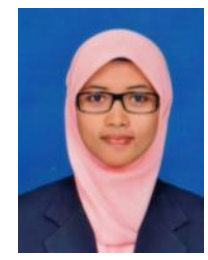

Mohd Amin is a postgraduate student currently studying in technical and vocational education at Universiti Tun Hussein Onn Malaysia. The research was conducted on the Indicator of learning content for the equivalence checking between the skills and academic in Accreditation of Prior Experiential Learning (APEL). Other than that, Mohd Amin also research about the enhancement of qualification framework for good practice in APEL.

Peer-review under responsibility of $3^{\text {rd }}$ Asia International Multidisciplanry Conference 2019 editorial board (http://www.utm.my/asia/our-team/) (C) 2019 Published by Readers Insight Publisher, lat 306 Savoy Residencia, Block 3 F11/1,44000 Islamabad. Pakistan, info@ readersinsight.net This is an open access article under the CC BY-NC-ND license (http://creativecommons.org/licenses/by-nc-nd/4.0/). 


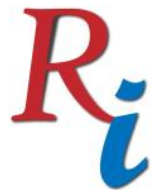

Asia Proceedings of Social Sciences

(APSS)

www.readersinsight.net/APSS

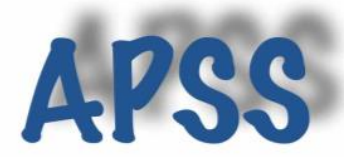

\section{Rese a r ch H i g h I igh t s}

This pilot study is to get feedback / input on items for nine (9) domain indicators that will be used for the determination of learning content in the equivalence checking between the skills and the academic for the APEL process. APEL helps in opening opportunities for individuals with the experience of gaining access to higher learning institutions as well as obtaining credit in learning through equivalence checking. The findings show that all the items in the Content Learning Indicator in equivalence checking between skills and academic for the APEL process are very appropriate.

\section{Research Objectives}

Provide research aims / purpose / objectives / significance with in 200 words.

The study is aimed to fulfill the development and implementation of the APEL system in Malaysia with the construction of a structured assessment tool that can determine the learning content of a module for equality research between the areas of expertise to the academic field. This is because of the individual difficulties that come from the skills field to put themselves in the academic program (Kaprawi, 2010). The objective of this study is to determine the items for each indicator used in learning content in equivalence checking between the skills into the academic. The importance of this study is to facilitate a person with the skills and experience to continue learning to a higher level and to cultivate lifelong learning. Mohamad (2002) states that knowledge based on the work performed can be recognized as the formal learning of individuals in the educational institute. At this pilot level, researchers have developed items for indicators that can determine the learning content of a module for the equivalence checking between the areas of expertise to the academic and the improvement studies should be carried out to carry out a real study.

\section{Methodology}

The model used for this study is the model of equivalence checking that adapted from the Oldenburg Accreditation Model by Muskens (2006). This pilot study uses a quantitative approach which uses questionnaire. Konting (2005) states that the use of the questionnaire can help to get consistent study responses. A total of 32 respondents consists of Dean, Deputy Dean and Head of Departments from seven (7) Faculty of University Tun Hussein Onn Malaysia. Purposive sampling was selected for this study because the respondents were limited. According to Idris (2010), that a packet is intended to involve individual considerations for selecting samples, based on researcher's knowledge and specific research purposes. For this study, the sample used is comprised of individuals who are directly involved in the field of skills and academic education. The questionnaire has 10 parts:
A: Demographics
B: Domain 1(Knowledge (Current))
C: Domain 2 (Practical Skills)
D: Domain 3 (Social Skills and Accountability)
E: Domain 4 (Values, Attitudes and Professionalism)
F: Domain 5 (Communication Skills, Leadership and Teamwork)
G: Domain 6 (Problem Solving Skills and Scientific Skills)
H: Domain 7 (Skill Management, Entrepreneurship and Innovation)
I: Domain 8 (Information Management and Lifelong Learning)
$\mathrm{J}$ : Domain 9 (Interdiscipline) 


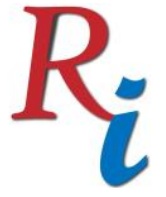

Asia Proceedings of Social Sciences

(APSS)

www.readersinsight.net/APSS

\section{Results}

The following is a result of the pilot study:

\section{i.) Domain 1}

This domain has 18 items. 3 items need to be removed.

\section{ii.) Domain 2}

This domain has 5 items. One item got incomplete and another item got a high consensus. But both items are agreed and maintained.

\section{iii.) Domain 3}

This domain has 8 items. Experts give a high consensus and median value.

\section{iv.) Domain 4}

This domain has 5 items. The mean value of 2 items is low and expert's consensus to remove the item.

\section{v) Domain 5}

This domain has 10 items. Experts highly consensus to remove 3 items based on the min value is low.

\section{vi.) Domain 6}

This domain has 8 items. One item got a high consensus to drop.

\section{vii.) Domain 7}

This domain has 12 items. 6 items did not get the expert consensus. However, these 6 items are at consensus-upon level and are still maintained.

\section{viii.) Domain 8}

This domain has 5 items. Experts give a high consensus and median value.

\section{ix.) Domain 9}

This domain has 5 items. 2 items did not get an expert consensus. Both items are at an agreed level and are still maintained.

\section{Findings}

Students with skill have to undergo a very high admission requirement set by the university. Their also take a very long learning time because the previous knowledge is not recognized. The equivalence checking from skill to academic is a development of relevant qualification mobility. This will be given opportunities for those in the area of skill to continue their studies at the higher academic level. All the domains (9 domains) and each item that built are very important also suitable in determining the content of the learning that will be used in equivalence checking between skills to the academic.

\section{References}

Idris, N. (2010). Penyelidikan dalam Pendidikan. Mc Grow Hill. Malaysia

Muskens, W. (2006). Permebility between VET and HE: The Experience of Module Level Indicator in Germany and its application in Austria. University Oldenburg.

Kaprawi, N. (2011). Leveraging Accreditation of Prior Experiental Learning (APEL) for Human Capital Development. Syarahan Perdana 2011. Universiti Tun Hussein Onn Malaysia.

Konting, M. N. (2005). Kaedah Penyelidikan Pendidikan. Kuala Lumpur: Dewan Bahasa dan Pustaka, Kementerian Pendidikan Malaysia.

Mohammad, M. (2002). Credit for Work Experience. International Postgraduate Facilitator Management CENTRE, Malaysia. 